Article

\title{
Precision Medicine and Advancing Genetic Technologies-Disability and Human Rights Perspectives
}

\author{
Aisling de Paor ${ }^{1, *}$ and Peter Blanck ${ }^{2, *}$ \\ 1 School of Law \& Government, Dublin City University, Glasnevin, Dublin 9, Ireland \\ 2 Burton Blatt Institute, Syracuse University, 900 Crouse- Hinds Hall, Suite 300, Syracuse, NY 13244-6070, USA \\ * Correspondence: aisling.depaor@dcu.ie (A.d.P.); pblanck@syr.edu (P.B.); Tel.: +353-1-700-6471
}

Academic Editor: Maya Sabatello

Received: 30 March 2016; Accepted: 10 August 2016; Published: 30 August 2016

\begin{abstract}
Scientific and technological developments are propelling genetics and genetic technologies into the public sphere. Scientific and technological innovation is becoming more refined, resulting in an increase in the availability and use of genetic testing, and other cutting edge genetic technologies, including gene editing. These genetic advances not only signal a growing trend towards precision medicine, but also provoke consideration of the protection of genetic information as an emerging human rights concern. Particular ethical and legal issues arise from a disability perspective, including the potential for discrimination and privacy violations. In consideration of the intersection of genetics and disability, this article highlights the significant concerns raised as genetic science and technology advances, and the consequences for disability rights, particularly the core concepts of non-discrimination, and respect for diversity and difference. On examining international human rights perspectives, it looks particularly at the UN Convention on the Rights of Persons with Disabilities and how it may be used to guide best practice in this area. With an acknowledgement of historical abuses of genetic science, this article highlights the need to maintain caution as to the potential consequences of advancing genetic technologies on persons with disabilities and indeed on society as a whole.
\end{abstract}

Keywords: genetics; new technologies; disability; law; human rights; regulation

\section{Introduction}

Scientific and technological developments are propelling genetics and genetic technologies into the public sphere. Scientists are uncovering a wealth of information about the cause and effect of disease, disability, and the range of common illnesses. As more scientific discoveries are being made in the genetics field, technological innovation is becoming more refined, resulting in an increase in the availability and use of genetic testing, and other cutting edge genetic technologies. Most recently, technologies such as gene editing (including the much publicised CRISPR/Cas9 technology) are coming to the fore, offering the potential for genetic modification and ultimately the eradication of disease.

These genetic advances signal a growing trend towards precision medicine (or personalised medicine as it is sometimes referred to) [1], whereby medicine, health care and treatment plans are developed and tailored to an individual's unique genome. Although offering unparalleled opportunities for understanding health and medicine, the advent of genetics and precision medicine exposes unknown territory, uncovers unintended consequences and highlights a minefield of ethical and legal quandaries in both medical and non-medical contexts, and indeed in society in general.

These developments provoke consideration of the protection of genetic information as an emerging and global human rights concern. Particular ethical and legal issues arise from a disability 
perspective, including the potential for discrimination, privacy violations, concerns about the principle of informed consent and challenging considerations about the concept of personhood [2]. The misuse of genetic information in social and economic contexts, as well as in society generally, intensifies the susceptibilities of persons with disabilities (including those genetically predisposed to disability), who are already in a vulnerable position and who already may be stigmatised and experiencing economic and social discrimination and exclusion [3]. Indeed, genetic advances provoke further legal, policy, and social questions regarding the concept of disability as well as the perception of persons with disabilities. Such advances may lead increasingly to the view of disability as a flaw or abnormality, thereby devaluing the lives of persons with disabilities. In addition, and in conjunction with genetic advances, there has been a growing rise in the voice of the disability community and an increasing recognition of the rights of persons with disabilities [4,5].

In consideration of the intersection of genetics and disability and the impact of advancing genetic science and new technologies, the objective of this article is to extrapolate the key ethical and legal issues arising from a disability perspective, highlight the current best thinking on the social construct of disability, and examine how it can shape the discussion in this area. In taking a disability rights perspective, this article will discuss the significant concerns raised as genetic science and technology advances, and the consequences for disability rights, particularly the core concepts of non-discrimination, and respect for diversity and difference. Further, the legal concerns and moral dilemmas arising over the use and potential misuse of genetic technologies, as highlighted in this article, may arguably inhibit or threaten the promise of precision medicine.

In framing this discussion, this article examines international human rights perspectives and explores the scope of the relevant United Nations framework in this area. It will look particularly at the UN Convention on the Rights of Persons with Disabilities (CRPD) and how it may be used to guide best practice in this area. It will further consider the extent to which the CRPD human rights approach may offer a framework for addressing this field from a policy perspective, with a view to acknowledging and protecting human rights. With an acknowledgement of historical abuses of genetic science, this article highlights the need to maintain caution as to the potential consequences of advancing genetic technologies on persons with disabilities and indeed on society as a whole. Lastly, we advocate a need to address and control the use of genetic technologies, with a view to anticipating the development of new forms of social and structural stigma and discrimination against persons with disabilities.

\section{A Genetic Science Primer-Current and Future Perspectives}

The past century has witnessed great progress in the field of genetics from the discovery of the DNA double helix to the successful completion of the Human Genome Project, as well as a growing use of genetic testing [6,7]. These and subsequent scientific developments have provoked a worldwide interest in genetics and prompted increasing efforts to learn more about the genetic make-up of human beings, as well as the reasons behind disease and disability. These advances have prompted technological innovation and the development of increasingly more refined genetic techniques.

Advancing genetic technology offers the possibility of precision medicine, which, in the future, may transform and tailor health care. The growing promise of precision medicine may facilitate and enhance an individual's autonomy, choice and effective management of their healthcare. A more refined understanding of a patient's genetic makeup enhances the care available and treatment. It offers the potential of earlier diagnosis, intervention and treatment of a wide range of diseases and conditions, as well as the avoidance of drug side effects [8,9]. From a wider societal and public interest perspective, the specter of precision medicine, notably recent developments with gene editing technologies, offers the potential to eradicate serious and life threatening diseases and other conditions from the human race. Genetic technology is becoming more prevalent and will inevitably be used in mainstream health care practice. The speed at which the science is advancing is clear, as is the speed at which genetic technologies are becoming more sophisticated and less costly. The result is 
a greater availability of genetic testing (and other cutting edge technologies) and a proliferation of genetic information.

The use and availability of genetic testing (and other genetic technologies), a technique which "involves examining a person's DNA for some anomaly that flags a disease or disorder" [10], is becoming more evident. Suspected mutations and predisposition to disease and disability may be confirmed by genetic testing in advance of the onset of symptoms [11]. As a predictive and diagnostic tool, the objective is that suspected genetic abnormalities and predisposition to disease may be confirmed and ruled-out by genetic testing, before the expression of symptoms. In other words, genetic testing (or screening) is the process of scanning an individual's genetic make-up to ascertain if the individual has a genetic predisposition to developing or passing on a genetic defect or disease [12]. In addition to identifying genetic markers for disease and disability, genetic testing may also ultimately identify behavioural and personality traits, thereby revealing further personal insights about individuals $[13,14]$.

There is a also growing accessibility to genetic testing, for example, as evidenced by the increasing profile and growth in the Direct to Consumer (DTC) genetic testing industry [15-17]. The growing market for DTC genetic testing may promote awareness of genetic diseases, allowing consumers to take control of their genetic health and a more proactive role in their health care. Whole genome sequencing is similarly becoming more refined and and accessible [18,19], offering significant application and opportunities in healthcare and facilitating the practice of personalised medicine. This technique involves a process that determines the complete DNA sequence of an organism's genome at a single time $[18,19]$, providing "a whole picture of an individual's genome, including susceptibility to disease and disability" [6]. With the decreasing cost of whole genome sequencing (and claims that a genome can now be sequenced for less than $\$ 1000$ [20]), it is likely that this technology will become routine in health care in the future [21,22].

Genetic advances have propelled the advancement of innovative technologies in the area of reproduction and assisted reproduction, with the aim of identifying genetic mutations and future disabilities, at the pre-natal stage, the antenatal stage and even at the pre-implantation stage [23]. These technologies identify treatable genetic disorders, generally before the expression of conditions, with a view towards earlier diagnosis, intervention and treatment [23]. Preimplantation genetic diagnosis (PGD) involves screening embryos and is a technique used to identify genetic abnormalities in embryos created through in vitro fertilisation $[24,25]$. This technique, although offering significant benefits to reproductive medicine and enhancing reproductive autonomy (with greater choice and treatment plans) [26], produces concerns in deciding in what circumstances to pursue pregnancy. Use of these technologies arguably provokes ethical issues such as the value and dignity of all individuals, particularly persons with disabilities, as discussed below [27].

Reproductive and other emerging genetic technologies, including gene-editing technology, are being discovered and refined at an exponential pace. One gene-editing innovation that requires immediate attention is CRISPR/Cas9. Hailed as a "game changer" [28], CRISPR/Cas 9 is a gene editing tool that is coming to the forefront of science and medicine, and is gaining media attention around the world. CRISPR stands for 'Clustered Regularly Interspaced Short Palindromic Repeats' and the technology facilitates scientists in making precise changes or modifications to human genes [29]. It has been described as "cheap, quick and easy to use" [28], thereby indicating the potential for significant application in the field of genetic science and medicine. Amongst other things, scientists hope to use CRISPR to eliminate serious disease (and disabilities), such as hereditary neurological conditions, cystic fibrosis and different types of cancer.

In addition to use in research, genome editing may also be used on human embryos, with a view to preventing genetic-based disorders and disease. Any genetic modifications made to an embryo will impact the genes and cells of an adult, with implications for future generations. It therefore has far-reaching implications and may inevitably have a radical impact on medicine and the human race. Although this "game changing" technology offers advantages in potentially eliminating debilitating 
disease and genetic conditions, there are potential pitfalls and a need for caution. Apart from the ethical and legal dilemmas, which are discussed below, the technology is at a relatively early stage and there is much to be done to ensure CRISPR is used safely and efficiently [28]. A genetic modification may produce a myriad of undesirable and unexpected effects in an individual's body, and indeed that of future generations.

In February 2016, scientists in the United Kingdom were given the authorisation to genetically modify human embryos for the first time by the UK Human Fertilisation and Embryology Authority [30]. Although these scientific activities are currently permitted only to take place in a research context (and cannot be implanted for reproductive purposes), this is a significant policy statement by a national regulatory authority in this field, which inevitably will have implications on other international policy endeavours [30].

\section{Future Perspectives on Genetic Technologies}

Rapid evolution in the field of genetic science projects a future in which a significant amount of information about genes and disease, as well as a means to manipulate and modify genes will become available and potentially public. It is inevitable that genetic technologies will become a more routine element of healthcare, creating new horizons in the scientific and medical fields. Through these advances, genetic technologies will propel the practice of personalised or precision medicine [1]. They also arguably facilitate greater patient autonomy and choice in diagnosis, treatment and in some cases, eradication of disease [31].

However, in conjunction with acknowledging the enormity of scientific and technological advances in this field, it is important to be "mindful of potential misuses, misunderstandings and pitfalls so that the promise of the genetic revolution in progress can be realised without undue costs and risks" [32]. Today's genetic revolution has generated a myriad of ethical and legal concerns, especially in relation to the misuse of genetic technologies. Specific concerns arise from a disability perspective, particularly in acknowledgement of a growing recognition of the rights of persons with disabilities. Advances in genetic science and technology arguably threaten the rights and indeed the value of persons with disabilities by highlighting disability as something that needs to be warned against or eradicated in society [33].

Linked to this and notwithstanding the advances that have been made in the field of genetics, it is necessary to be aware of the limitations of genetic technologies [34] and, in particular, to acknowledge the interaction of genes and environment and the role of external factors in the expression of disease and disability [35]. The technology, although advancing, is at a relatively early stage, in terms of predictability [36]. Predicting the onset of disease or disability through use of genetic technologies is dependent on a variety of components, including environmental factors, as well as "variances in gene expression, accuracy of the test, and the stability of linkage between genetic markers and suspect genes" [37]. Indeed, gene editing technologies are at a relatively premature stage, and much is unknown about the effect of using these technologies [38]. The uncertain nature of these techniques may provoke a range of unintended consequences. In addition to safety concerns, the limited predictive value of genetic technologies is important to note, not only from a clinical perspective, but in the context of identifying potential misuse of the technologies in medical, third party and other settings.

\section{Genetics and Disability}

The intersection of genetics and disability has provoked debate and discussion amongst the disability community and those concerned with social justice, as well as in the scientific community and those advocating the advancement of genetic science [39-41]. In conjunction with genetic advances, there is a growing proportion of the population with disabilities [33,42]. The existence of an ageing population may also expand the proportion of those with disabilities or future disabilities. Particularly challenging views and questions are likely to arise, in the disability community and society in general, as genetics advances with the advent of cutting-edge technologies such as gene editing. From a 
disability viewpoint, advancing genetic science and technology may be viewed from a number of perspectives. As will be highlighted in the following sections, some may view these new technologies as a means of ameliorating or eradicating disability, while others view these developments cautiously. This article takes a disability rights approach and urges caution in the use and application of genetic science and new technologies.

Genetic technologies provide a new lens through which to view (to identify, as well as eradicate) disability [36]. Genetic testing and emerging technologies offer the possibility of detecting the onset of future disability and disease, through genetic testing and screening techniques. From a theoretical perspective, the predictive potential of genetic technologies highlights the broad concepts of future disability, perceived disability, and imputed or putative disability. These technologies also offer the potential to eradicate (or ameliorate) disability in humans, through techniques such as gene editing. The ability to intervene to prevent or ameliorate disease or disability, not only in adults, but also at prenatal and preimplantation stage is thereby pushing the boundaries of traditional and existing conceptions of disability and threatening the human and civil rights of those with current and future disabilities [43].

The prospective of eradicating disability may have particularly far-reaching consequences in medicine as well as from a societal and an ethical perspective. Developments in genetic technology and in particular the advent of gene editing are changing the way we perceive who is "normal" and who is "disabled" [44]. Indeed from one perspective, "if everyone has genetic conditions that are just waiting to express themselves in the future, isn't everyone truly disabled" [44]. Considering that nobody has perfect genes, it has been observed that "as we will all have knowledge of the potential genetic disorder that we each harbor, disabled people may no longer remain stigmatized as "the other" in society [44]. On the other hand, and more concerning, is the prospect that new technologies and the growing vista of precision medicine create the potential to further stigmatise disability and change perceptions of what is normal and even acceptable in society, by highlighting disability or genetic difference as something that should be avoided or at least preempted.

As discussed in the following sections, new issues therefore arise around the perception of persons with disabilities, from a variety of perspectives. Advances with technologies (such as gene editing) reflect the view that disability is an abnormality instead of a natural feature of human diversity [45]. Without caution, they may lead to the widespread view that persons with disabilities are inferior. They also may operate to devalue the lives of persons with disabilities and persons with future disabilities.

\section{Stigma, Genetics and Disability}

Linked to the concern of viewing disability as an abnormality, advancing genetic science and technology may shape, inform and provoke undesirable societal stigmas in this field. Indeed societal stigmas may shift and the notion of disability is likely to transform and develop to encompass a larger portion of the population including those with genetic predisposition to disease or disability [46]. These advances provoke challenging questions regarding the way in which society conceptualises and views human difference. Advancing genetic science may amplify long-standing ambivalence that society has towards human difference and diversity [5]. The issue of stigma [47] around disability and surrounding genetic predispositions to disability highlights the vulnerable position of persons with disabilities and the propensity for further discrimination and isolation in this new genetic era.

Through stigmatising attitudes and actions individuals are devalued, rejected and excluded [47]. Stigma results in a "vicious circle" that may lead to discrimination and other mistreatment [48]. Individuals with certain medical conditions and disabilities face stigma on the grounds of perceived defects, traits and inabilities. Such defects, traits, and assumed inability may lead to a perception of such individuals as inferior and lacking value or acceptance in society. The stigmatisation of individuals (and their family members) with physical and mental disabilities is widespread [49-51]. This stigma and stereotyping may result in unlawful discrimination, and a lack of respect and isolation from society. This issue of stigma is evident across society and in commercial contexts, for example, 
in the employment relationship [52]. Thus, in third party contexts, such as employment, negative attitudes and stigmatising views on the part of employers may result in a reluctance to hire individuals with disabilities (or genetic predispositions to disability) and act as a barrier to employment. Employers may perceive such persons to be unproductive, unreliable and in certain cases a danger to themselves and the public [53]. Employees and potential employees may experience discrimination in terms of access to employment, and generally, in respect of promotion or other benefits of employment such as health care [54].

Regarding the issue of stigma, Bickenbach remarks that genetic information may become "the most profound form of stigmatising labeling people with disability have as yet experienced" [55]. He suggests "human difference, when labeled genetically, opens the door to the most profound forms of stigmatisation" [55]. Indeed, new genetic technologies may operate to shape and exacerbate the stigma surrounding disability and difference, opening the door to societal rejection and profound forms of mistreatment. Such stigmatisation may translate into overt and subtle discrimination against individuals on the basis of genetic information, as well as other harmful treatment and violation of privacy [36].

\section{Emerging Ethical and Legal Concerns}

\subsection{A eugenics Framework}

On exploring the connection between genetics and disability, and with a view towards highlighting the propensity for new forms of misuse in this genetic era, it is relevant to consider the concept of eugenics and the eugenics movement which swept the early twentieth century. The eugenics movement and historic efforts to eliminate genetic-based disease and disability have long been established [5]. Persons with disabilities and those presumed to be genetically inferior were particularly targeted by the eugenics movement.

Francis Galton initiated eugenics as a concept, with support from Charles Darwin in the 19th century $[5,56]$. It has been described as the "conscious selection of humans by encouraging the production of those with desired inherited characteristics and restricting those with undesirable inheritable characteristics" [57] or "the use of science applied to the qualitative and quantitative improvement of the human genome" [58]. Since the 19th century, there has been recognition of the potential of using science and principles of inheritance to shape eugenic policies, with the result of creating a genetically "cleansed" society [59].

Eugenics reflects how genetic knowledge and a misinterpretation of genetic science may correspond with oppressive public policy to deny individuals their fundamental rights, particularly individuals with disabilities and other vulnerable populations. Historical misapplication of genetic science is a key consideration for examining the ethical dilemmas and challenges of today's genetic era. The eugenics movements of the early twentieth century, such as those in Europe and the United States (US), provide insight into the potential misuse of science, and offer a framework for consideration of modern day eugenics and misuse of genetics. It has been observed that "by remembering and understanding the past injustices and inhumanity of negative eugenics, further misuse of scientific information can be avoided" [60]. In Europe and the US, the eugenics movement aimed to promote and advance genetic superiority, and it endeavoured to achieve this primarily by sterilising persons with disabilities and those deemed genetically inferior [61]. In Europe, the German T4 Euthanasia programme is illustrative of such a repressive application of genetic science. This programme began in 1939 had the objective of eliminating those with physical and mental disabilities, and other vulnerable members of society $[62,63]$. Repressive regimes were also implemented in Scandinavia, which similarly deprived individuals of fundamental human rights in the search for genetic superiority [64].

Eugenic policies in the US were experienced throughout society, including in the areas of immigration and family life [59]. In the 1920s, state fairs sponsored "Fitter Families" competitions, which awarded prizes for those deemed to be "Grade A individuals" [65]. At this time, many US 
states introduced sterilisation laws targeting what were perceived to be genetically defective groups, following early developments in genetic science. The policy rationale advocating such sterilisation was that those individuals were costly for society [66]. From 1907 to 1937, thirty-two American states introduced compulsory eugenic sterilisation laws, with the objective of controlling the reproductive capabilities of those deemed to be genetically inferior $[67,68]$. The US Supreme Court promoted sterilisation in support of eugenics in its landmark decision of Buck v. Bell, with Justice Oliver Wendell Holmes infamously stating " ... three generations of imbeciles is enough ... " [69].

\subsection{Genetics and a New Age of Eugenics}

With genetic science advancing and the benefits of science being realised, eugenics considerations are again rising to the surface and raising questions as to disability discrimination, stigma and a new "subtle" eugenics developing. In this age of "new genetics," the ethical, legal and social implications of genetic technologies have become more intricate, however, the controversies and societal risks it raises are effectively the same [70]. New genetic technologies offer means of differentiating and potentially discriminating against individuals, particularly those with disabilities and putative disabilities. These technologies offer the potential to identify and eradicate disabilities, and eradicate fetuses with disabilities, creating ethical dilemmas around the value of a life, and eugenic tendencies.

In the reproductive context, there has been much discussion in this area. The use of pre-natal genetic testing or PGD may cause concern and it may be claimed that selection against genetic impairments amounts to discrimination against persons with disabilities [5,71,72]. It has been pointed out that PGD arguably "meets the definition of eugenics" and may be viewed as a "negative selection tool" [73], in terms of selecting the implantation of embryos with particular genetic traits and excluding the implantation with embryos deemed to be genetically flawed or inferior [73]. The advent of gene editing is challenging in this regard, provoking questions concerning a reinvigoration of eugenics. Gene editing may facilitate a new eugenics of personal choice in health care and reproduction, whereby humans dictate their own "disability free" evolution individually and throughout future generations. These new genetic technologies, particularly gene editing, have the potential to idealise the perfect person with perfect genes, and a population founded upon genetic desirability [74]. They provoke concerns about the potential trend towards 'designer babies' or designer individuals [75,76]. Thus, will such babies be designed without disabilities or impairments? And, will disabilities be screened out? Genetic technologies certainly provide the possibility for such a trend, which creates a myriad of moral dilemmas for society and potentially threaten the human and civil rights of persons with disabilities. Taken a step further, the potential for designer babies may open the floodgates towards selecting traits and characteristics such as eye colour, height, sporting ability and even intelligence, creating further ethical quandaries [77]. The trend towards designer babies and use of genetic technologies in reproduction also may produce unintended consequences, such as genetic selection for impairment or disability [43], which arguably provokes consideration of the "right to disability" [43], as well as the right to protect culture and family autonomy [78]. As is evident, genetic developments in this field produce a variety of consequences, and ignite discussion from a variety of perspectives and moral standpoints.

The complexity of this debate in the disability context reflects the reality that persons with disabilities (and their families, caregivers and supporters) perceive their human condition in a variety of different ways [79]. In addition, those in the disability community have different viewpoints regarding medical and technological advances, with some advocating the need for medical cures and genetic intervention, and others focusing on what is perceived as the more important need to remove social barriers $[43,80]$. Reflecting a perspective from the genetics community, geneticist James Watson, who discovered the double-helix structure of DNA along with Crick [81], stated that "seeing the bright side of being handicapped is like praising the virtues of extreme poverty" [82]. In this respect, new genetic technologies are viewed favourably, as a means of ameliorating disability, and improving the lives of individuals. From a disability rights perspective, these views are arguably regressive and 
reflect a medical model construct, whereby persons with disabilities are viewed as inferior, worthless and in need of improvement [79,83-86]. According to the medical model, in which disability is seen as a problem inherent in the person, caused by biological defect, disease or other health conditions [87], it is generally perceived as giving rise to the perception of the individual having a low quality of life and being below-normal $[4,88]$.

In further reflecting the complexity of this debate from a disability perspective, the proliferation of genetic technologies has the potential of devaluing the lives of persons with disabilities and persons with future or putative disabilities [73]. In addition to testing for the presence of genetic conditions, the objective of PGD and other such technologies is to enable parents "to avoid having a child with a disability" [73]. Gene editing takes this argument a step further in terms of striving for genetic perfection and ultimately reflecting eugenic tendencies. If genetic perfection or genetic superiority becomes the norm, this may exacerbate the stigma of those with disabilities, and indeed of those individuals and their parents who decide not to undergo such testing or to avail of cutting edge genetic techniques. These individuals may potentially be viewed as the 'other' in society. It may also exacerbate the propensity for discrimination against those with disabilities and genetic predispositions to disability, as discussed below.

Such technological possibilities are arguably reflective of Savulescu's theory of "procreative beneficence," which advocates the moral obligation to have the best children possible-including through use of genetic technologies $[89,90]$. In other words, parents have an obligation, which may translate as a parental responsibility to avail of emerging genetic technologies, with a view towards avoiding disability. Linked to this is the issue of parental or reproductive autonomy and freedom. Some would argue that parents should have the unfettered right to decide the means and method of reproduction, including the right to avoid (or select) disability. A conflict arises here, and particularly from a disability rights perspective, between parental autonomy and ethical concerns around the value of life and respect for difference and diversity [91].

Indeed, such theories have been criticised by the disability community, in terms of devaluing the lives of persons with disabilities [92,93]. Likewise, the disability community has critiqued the pursuit of genetic perfection [27]. Through permitting the power to select against difference, a few in society will be selecting for intolerance of human difference. From a disability perspective, the emergence of genetic technologies and the introduction of genetic screening policies (and recent technologies such as PGD and gene editing techniques) sends the message that disability and difference is unwelcome in society [94,95]. Technologies such as PGD and gene editing in particular advocate an intolerance of difference and disability, and offer a means to select against (or in favour of) disability. It provokes challenging questions about the types of individuals that may be born, now and throughout future generations. The history of the eugenics movement provides a framework for viewing the ethical dilemmas that are apparent as genetic science and technology continue to advance today. An examination of the abuses of the past offers insights into potential future misuse of science and technology, and warns against uncontrolled use of new technologies and the reinvigoration of eugenics in today's society.

On considering debates surrounding use of genetic technologies and disability, it is acknowledged that the area and the subject matter is inherently complex and fraught with difficult ethical dilemmas. The question may arise as to whether use and application of genetic technologies (particularly PGD and gene editing) to address and eradicate serious diseases and disabilities is justified and, if so, under what circumstances [91]. It may be argued that this use of these technologies is acceptable and even necessary from the perspective of improving lives and eliminating serious disease and life threatening illness, as well as enhancing personal choice, autonomy and reproductive freedom. However, the use of such technologies for what may be perceived as less serious disease or disability, or for non-therapeutic or aesthetic purposes, may be a less compelling argument from a moral standpoint [91].

The new genetic era and forms of subtle eugenics therefore give rise to public policy concerns and signal the need to anticipate the creation of a genetic underclass in society and respond to these 
issues [96]. The rise of a genetic underclass raises serious ethical and public policy concerns [97]. Advancing genetic technologies, and uncontrolled use of such technologies may lead to societal intolerance of disability and genetic difference. Accordingly, questions arise as to how to address and control the use and potential misuse of genetic technologies, and the appropriate regulation of this area [98]. In consideration of the need for governmental regulation, it is necessary to identify and anticipate misuse of genetic technologies and potential human rights at stake.

\subsection{Disability Discrimination and Other Concerns}

In conjunction with concerns about stigma and a reinvigoration of eugenics, persons with disabilities and persons genetically predisposed to disabilities as well as their family members [99] may experience increasing discrimination and mistreatment in society, as well as in a range of third party and commercial contexts, including employment and insurance [96]. In addition to discrimination on the grounds of disability at a societal level and a potential trend towards an intolerance of disability, genetic information is valuable to third parties and may be viewed as a predictive tool primarily for economic reasons $[100,101]$. The implications of such third party interest in genetic information has been widely debated and discussed in the literature, and is reflected in legislative endeavours in the field.

Genetic discrimination may be defined as "discrimination directed against an individual or family based solely on an apparent or perceived genetic variation from the 'normal' human genotype" [102-104]. It describes discrimination on the basis of genetic information, genetic makeup or family medical history (which is a key source of genetic information) [105-107]. From a disability viewpoint, the concept may describe discrimination on the basis of future disability, imputed disability or genetic predisposition to disability [98]. New technologies such as gene editing, however, are creating another dimension of genetic discrimination. As discussed above, these new technologies, with the objective of eradicating disease and disability may provoke an intolerance of difference and disability. Such intolerance may lead to discrimination against those who currently have disabilities or genetic conditions; for example, that are not eradicated or ameliorated by existing genetic technologies or techniques. It may also lead to discrimination against persons with putative or future disabilities and genetic susceptibilities who either choose not to use genetic technologies to enhance or improve themselves, or who are not born through use of genetic screening or editing techniques.

Related privacy concerns arise with a growing availability and accessibility to genetic information, particularly in the digital world [108]. Unauthorised access to and use of genetic information may violate an individual's privacy [109]. This concern is heightened given the personal and private nature of genetic information, as well as the familial nature of genetic information. All individuals are entitled to protection of their privacy as a fundamental human right [110]. In acknowledgement of the personal nature of genetic information, genetic privacy "protects personhood interests in shielding us against stigmatization, discrimination and being misunderstood" [111].

Employers may seek to access or use an employee's genetic information for economic purposes and as a mechanism for selecting what are perceived to be the most desirable, genetically attractive employees, who are least likely to be sick, injured on the job, and cost the employer money and time $[100,101]$. It may be assumed by employers that healthy employees who are perceived to be genetically attractive do not carry financial risks. In light of the predictive character of genetic information, there are incentives for employers to seek access to genetic information in the workplace for financial benefit [112]. In light of obligations under health and safety law (both under common law and legislation), employers also have a concern for protecting the safety and welfare of the employee and the prospective employee, as well as of co-workers. In some circumstances, employers may seek to access employees' genetic information or request genetic testing of employees who, because of their genetic makeup, may be at an increased risk of developing certain illnesses if exposed to occupational hazards [113,114]. 
Similarly, use and misuse of genetic technologies and genetic information may occur in the health and life insurance context. As a profit oriented industry, private insurance companies have strong incentives to seek access to genetic information, through genetic test results and analysis of family medical history. Private insurers may advocate use of genetic information to facilitate improved underwriting through more accurate risk classification, to reduce the practice of adverse selection [115], and result in a more efficient system of insurance [116]. Further arguments may be advanced that fundamental principles of insurance law such as the duty of disclosure and utmost good faith demand disclosure of all relevant information [117].

This third party interest in using genetic information likely conflicts with an individual's rights, for example, the right to privacy, the right not to be discriminated against, as well as the right to autonomy. It may also conflict with an individual's (and family member's) right not to know their genetic information [118]. Employers and insurance companies arguably have no right to request and require that an individual undergo genetic testing or use the results of genetic tests previously taken [96]. Decision-making on the basis of the probability of an individual developing a certain disease or disability, as opposed to current health status or on the actual ability to perform the work, may be deemed to be unlawful discrimination [96].

From a practical and clinical perspective, further challenges arise around the issue of informed consent regarding the use (and potential future use) of new genetic technologies [119]. The concept of informed consent is a reflection of the inherent right to autonomy. Considering the wealth of information discoverable through use of genetic technologies, its meaning and implications, as well as the implications for family members and others (such as third parties), informed consent is paramount in the field of genetics. Use of genetic technologies in the medical setting, as well as third party requests to use such technologies may challenge traditional conception of informed consent. Additional concerns surround the consent of future generations and future persons with disabilities to use (or non-use) of these technologies [43]. Considering the range of human rights at stake, these practical challenges and legal concerns need to be addressed and ultimately regulated.

\subsection{Personhood, Disability and Genetic Determinism}

From a philosophical perspective, genetic advances may have a profound effect on the notion of personhood and core concepts of humanity [120], as theories such as genetic determinism and geneticisation become prevalent. The concept of personhood may be influenced by advances in genetics, and it provokes consideration of the relationship between genetic information and personal identity. Personhood as a concept is differentiated from the notion of being human, which means to belong to a species [121]. Personhood represents one's recognition as a person-and "therefore as a 'subject' of the law and the political order-as a beneficiary of the system of justice" [121]. Concepts of personhood have evolved over time, particularly with changes in societal and cultural norms $[3,121]$.

In this new genetic age, with scientists making rapid discoveries about genes, it is likely that concepts of personhood and self-determination will further develop and evolve. Genetic information and the human genome relate to the biological component of personhood, and how this impacts the conception of what it means to be a person [120]. An individual's genetic information determines a myriad of characteristics and traits from height, skin colour, eye colour, gender, behaviour and personality. With scientific research revealing core elements of a human's unique make-up and other personal traits, this will have an impact on conceptions of self [120].

The impact of genetic information on personal identity accordingly provokes consideration of the concepts of genetic determinism and genetic reductionism [122]. With focus on the importance of genes on the expression of disease and disability, there is an increasing potential for promotion of the "geneticized self;" in other words, reducing one's identity to a genetic basis $[123,124]$. These notions of the "geneticized self" raise ethical concerns, particularly in relation to concepts of humanity. With advancing genetic science comes an opportunity to enhance oneself, with implications for human dignity, uniqueness and difference. Such conceptions of self do not acknowledge the complete 
person. Within the genetic conception of self, "the person then becomes no more than their 'bad' genes" $[123,124]$, potentially leading to discrimination and stigmatisation, thereby compounding the mistreatment of persons with disabilities (and genetic predispositions to disability).

Some theories of genetic determinism suggest that our genetic profile is "the dominant causal arbiter of all that we think, feel, and choose to do" [120]. Taken to the extreme, genetic determinism implies that a person does not possess the freedom to think, or choose. This conception is contrary to the interpretation of a person as an autonomous being who can freely choose between various courses of action [120]. Strict application of the theory of genetic determinism denies that individuals have the power of free choice. In response, there is a compelling reason for maintaining the concept of free will and rejecting genetic determinism: Such a theory would "wreak havoc on our ordinary conceptions of ethically responsible agency and moral desert" [120].

In reality, a developed view of genetics does not support the theory of genetic determinism. The nature of personal identity is found in the myriad of personal circumstances and facts that make up each person's life. A person's environment, occupation, and lifestyle choices contribute to one's sense of self. Only a few genetic conditions are solely determined by a certain gene or genes [123]. Accordingly, "genes are only one more influence in the contingent histories of our lives" [123].

From a human rights perspective, the concept of the "geneticized self" threatens an individual's basic human rights, particularly since they are then "defined out of humanity and potentially outside the boundaries of moral responsibility" [124]. There is a danger of an individual's identity becoming lost and his or her life becoming devalued, which arguably threatens the dignity and integrity of the person. These notions reflect the concept of personhood and of recognising the legal capacity of all individuals, as set forth in the CRPD's Article 12 [125].

From a disability rights perspective, over- and mis-reliance on genetic determinism and the biological component of disability and disease is undesirable and perpetuates the medical model conception of disability. This may also encourage stigma and provoke negative attitudes in this area. As has been pointed out, "an exclusive focus on genetic causation distracts from other important factors that cause or contribute to disability" [5]. In addition, considering the interaction between genes and environment, the majority of disability and disease is in fact usually caused from other illness, ageing, injury from war and other causes, apart from genetics [5]. Such an approach arguably runs contrary to the social model of disability, which endorses the external, environmental causes of disability, including negative (societal and individual) attitudes [83-86,126].

\subsection{Controlling the Use of Genetic Technologies}

Against the backdrop of scientific and technological advances, there is a growing potential for misuse of genetic technologies and a myriad of fundamental human rights at stake. Considering the rapid advances in genetic technologies, there is potential for a reinvigoration of damaging eugenic type policies emerging (aimed at those who are deemed to be genetically inferior) as well as growing stigma against persons with disabilities in society. Particular concerns arise around use of gene editing technologies. In acknowledgement of the potential for misuse and the fundamental human rights at stake today and in the future, appropriate governmental controls and regulation of this field are a necessity. There is a corresponding need for awareness raising in this area, particularly in consideration of the potential over-reliance on genetics and a possible trend towards genetic determinism in society. Within the human rights framework and in consideration of disability rights, it is important to consider international human rights perspective and examine how it might provide guidance on best practice in this field going forward.

\section{International Human Rights Framework}

Regarding the connection between genetics and disability and the application of the social model of disability, international human rights law provides guidance on the ethical and legal dilemmas arising in this field. A human rights-based conception of disability (and indeed genetic predisposition 
to disability) focuses on recognising and protecting the fundamental human rights of persons with disabilities on an equal basis with others. Of particular relevance is the CRPD mentioned earlier [127], the first international human rights treaty of the twenty-first century, which aims to facilitate the fundamental human rights and equal treatment of persons with disabilities [128].

\subsection{United Nations Convention on the Rights of Persons with Disabilities}

It is argued that the CRPD "calls into question" the compatibility of genetic technologies and screening policies with fundamental disability rights principles [129]. It provokes consideration of fundamental human rights, such as non-discrimination and equality, respect for dignity and integrity as well as privacy, and requires State Parties to acknowledge, recognise, and protect these interrelated rights.

The CRPD operates within the framework of the social model of disability, focusing outward toward the environment and external factors as creating barriers and disabling a person [133]. The CRPD has been described as "the highest legal manifestation and confirmation of the social model of disability on the international stage" [130]. Article 1(2) emphasises the social model and states: "Persons with disabilities include those who have long-term physical, mental, intellectual or sensory impairments which in interaction with various barriers may hinder their full and effective participation in society on an equal basis with others" [131], reaffirming the theory that limitations arise as a result of the interaction with artificial barriers in society [132]. The Preamble (e) provides that "disability is an evolving concept and that disability results from the interaction between persons with impairments and attitudinal and environmental barriers that hinder their full and effective participation in society on an equal basis with others" [133].

The CRPD "provides a fresh human rights read on the interrelationship of genetic technology and disability rights as reflected in international human rights law" [134]. In addition to urging caution as to the use of genetic technologies and emerging screening and modification techniques, it offers guidance on best practice and acts as an international forum for discussion of these issues.

The Committee on the Rights of Persons with Disabilities, in one of its first concluding observations on a state report, indicated its conception of disability discrimination in a situation directly related to genetic testing for disabling characteristics [134]. In particular, the Committee was critical of Spanish legislation on sexual and reproductive health (decriminalising termination of pregnancy) and indicated its "implicit linkage between disability discrimination and the termination policy in Spain with direct implications for genetic testing in the context of disability" [134], thereby suggesting that the approach of the Committee, in interpreting disability discrimination under the CRPD, potentially encompasses the prohibition of genetic testing.

\subsection{Genetics and the $C R P D$}

The misuse of genetic technologies resulting in the discriminatory use of genetic information at societal or individual level (and other human rights violations) is arguably contrary to the CRPD. In addition, genetic screening policies such as those that target Down Syndrome, for example, and other genetic-based conditions are contrary to the principle of non-discrimination as set out in the CRPD, in terms of identifying and eradicating certain disabling conditions as being undesirable and inferior. Recently, the development and application of new genetic technologies, resulting in discrimination against persons with (current and putative) disabilities may also be contrary to the CRPD. This section examines the application of the CRPD to the use and misuse of genetic technologies and highlights the obligations on State Parties in this area.

The principles of non-discrimination and equality are endorsed in the CRPD and one of the key frameworks adopted in the CRPD is that of non-discrimination. Non-discrimination as a premise in the CRPD is referred to in the Preamble (h), which states "... discrimination against any person on the basis of disability is a violation of the inherent dignity and worth of the human person" [135]. This formulation reflects the ethos of the Convention's non-discrimination and equality principles [136]. 
Article 5 provides for the principles of equality and non-discrimination. It requires the prohibition of discrimination "on the basis of disability" and guarantees to persons with disabilities equal and effective legal protection against discrimination on all grounds [137]. Discrimination on the basis of disability as provided for in the CRPD has encompasses individuals who are not themselves disabled but who are discriminated against on the grounds of their "association with an individual who has a disability" [138]. The phrase discrimination "on the basis of disability" is "wider than a definition that focuses on the peculiar impairments of any given individual" [138]. Article 5, with its focus on the actions of third parties and read in conjunction with the intention of the CRPD, may be interpreted as applying to discrimination on the basis of genetic information or genetic predisposition to disability. It also signals potential incompatibility with genetic technologies and techniques that aim to eradicate disability. At the very least, Article 5 encourages the appropriate (and when warranted, limited) application of these technologies.

Further non-discrimination provisions are evident in Article 27, which focuses on work and employment, recognising the right of persons with disabilities to work on an equal basis with others, and prohibiting discrimination on the basis of disability [139]. Article 27 (a) prohibits "discrimination on the basis of disability with regard to all matters concerning all forms of employment, including conditions of recruitment, hiring and employment, continuance of employment, career advancement ... " [139]. As indicated, use of an employee's genetic information may result in discrimination and the denial of employment opportunities on the basis of perceived disability, thereby violating Article 27.

\subsubsection{Right to Respect for Dignity and Integrity}

The right to respect for dignity and integrity underpins and informs the CRPD. Article 3 sets out the guiding principles in the Convention, which include dignity, autonomy, non-discrimination, full and active participation and inclusion, respect for difference and human diversity, and equality of opportunity [140]. Pursuant to these principles, respect for dignity is undermined or denied in circumstances where persons with disabilities are devalued and their lives disregarded [129]. Where genetic screening policies such as PGD, genetic testing and gene editing technologies advocate the eradication of disease and genetic conditions, the underlying message is that these conditions are burdensome and lacking in value [129]. Recent developments with gene editing technologies further advocate the desire to eliminate disease and disability from society, thereby devaluing the lives of those with such existing and future disabilities. Such practices employed in an adverse manner may also be viewed as contrary to a social model understanding of disability. One particular example is screening for Down Syndrome [141], which has no therapeutic value, and thereby operates to "reinforce the idea among persons with disabilities themselves that they are tagged with their impairments and thereby branded as a burden" [95,129]. Other examples include (prenatal and newborn) screening for conditions such as Cystic Fibrosis, Sickle Cell Anaemia and Tay Sachs Disease. A similar analysis may be applied to other more recent and more controversial genetic screening techniques, particularly in the reproductive context, whereby the technologies are pushing the boundaries of choice in reproductive decision-making and offering the potential to identify future disease and disability at an early stage and to avoid such conditions completely. Likewise, gene editing effectively screens out disability and genetic flaws, and these techniques may impact the perception of disability and difference for future generations, thereby exacerbating the stigma and negative perception attached to disability and genetic conditions [142]. Similarly, the principle of respect for difference and human diversity recognises disability as a natural incident of the human condition, and these principles may caution the use and application of such genetic technologies. The principles of respect for difference and human diversity reflect general human rights values and reinforce the ethos of the social model conception of disability [134].

CRPD Article 17 protects the integrity of the person and provides that every person with disabilities has a right to respect for his or her physical and mental integrity on an equal basis with others. Genetic science, and emerging genetic technologies, may operate as a tool of social 
manipulation and lead to the practice of genetic cleansing [61]. If this practice proliferates, and a societal perception towards "genetic perfection" develops, this may result in negative attitudes towards persons with disabilities as being inferior [61]. It may signal a reinvigoration of eugenic type attitudes and policies in society. This may have undesirable societal implications by categorising individuals according to perceived genetic status. In particular, the emergence of gene-editing may threaten the integrity of the person and have undesirable societal implications. In addition, the existence of barriers to employment, insurance and other social goods and services (as a consequence of misusing genetic information) may result in the exclusion of vulnerable individuals and violate the principles of dignity and integrity [143]. In protecting integrity, Article 17 encourages the appropriate application of genetics, with individual rights at the forefront.

\subsubsection{Awareness Raising}

Awareness raising is a central component of the CRPD in acknowledging and recognising the rights of persons with disabilities. It is relevant in terms of attitudes towards disability and perceptions of genetic predispositions towards disability. Cultivating environments of positive attitudes towards disability may improve attitudes towards genetic conditions and genetic predispositions. Article 8 requires a publicity campaign to "nurture receptiveness to the rights of persons with disabilities" and to promote recognition of the "skills, merits and abilities of persons with disabilities" [144]. It requires states to encourage the media to "portray persons with disabilities in a manner consistent with the purpose of the present Convention" [144]. In this regard, the CRPD may be utilised to address attitudinal barriers toward disability and genetic predispositions in the form of awareness raising [145]. The importance of this provision is that "a culture shift in attitudes ... could make the difference between rhetorical change and real improvement" [138]. It also may be used to encourage awareness and education about the impact and appropriate application of genetic technologies. In encouraging appropriate use and application of genetic technologies, awareness raising tools may be used to highlight the current limitations with genetic science and technology, particularly regarding accuracy and predictive value, as discussed above. Such awareness raising may positively impact the use, application and indeed the regulation of new and emerging genetic technologies.

\subsection{Evaluation of the CRPD}

The year 2016 is the tenth anniversary of the introduction of the CRPD and it is a time not only to reflect upon the importance of this instrument as the first ever disability rights treaty in securing fundamental human rights, but also for anticipating challenges that persons with disabilities face in today's world of genetic advancements and technological developments.

In acknowledging the intersection of disability and genetics within a human rights framework, the CRPD may be used as an impetus to develop reforms around the regulation of genetic technologies and initiate thinking about the concept of disability and disability discrimination so as to encompass putative disability and genetic predisposition to disability [36]. Discrimination concerns and subsequent threats to the dignity and integrity of persons with disabilities are at the core of this debate. In addressing these concerns, the non-discrimination framework is utilised by the CRPD as a method to secure fulfilment of the rights of persons with disabilities. This approach is complemented by emphasis on the concepts of human dignity and integrity as well as on the social model understanding of disability. The provisions and rationale of the CRPD may be interpreted to encourage caution and the uncontrolled use of new genetic technologies, with acknowledgement of the rights of persons with disabilities, and at the very least, participation of persons with disabilities in this discussion and in any law and policy endeavours. This instrument may be used to encompass the protection of genetic information in third party contexts-particularly by preventing discrimination, protecting privacy as well as awareness raising to advocate positive attitudes and education as to the benefits and limitations of genetics [143]. 


\section{International Soft Law}

In addition to the CRPD, there is a body of international "soft law", which offers guidance in terms of best practice for law and policy reform in this field [143]. These instruments include UNESCO's Universal Declaration on the Human Genome and Human Rights (1997) [146], the first universal instrument to introduce an ethical structure for activities in the area of the human genome, UNESCO's International Declaration on Human Genetic Data [147], "a sequel" to the 1997 Declaration [148], and UNESCO's Universal Declaration on Bioethics and Human Rights [149], "an important step in the search for global minimum standards in biomedical research and clinical practice" [150].

These documents reflect core values of non-discrimination and equality as guiding principles, and the Declarations speak in favour of protecting genetic diversity and prohibiting discrimination [143]. Human dignity is a common thread in the UNESCO Declarations in this area [151]. The concept of human dignity is central to respect for genetic difference, and acknowledging the nature of genetic information as unique to each individual. In addition, the reliance on "human dignity" reflects the submission that the protection of genetic make-up and information is a core human rights issue [152].

These soft law instruments, although they provide limited binding force "... provide evidence of the importance of human rights as a jumping-off point in the evolving body of international law and practice on the regulation of new technologies" [153]. Together with the CRPD, the Declarations highlight an international consensus for ensuring that genetic science advances with appropriate safeguards and an acknowledgement of the importance of human rights [143].

\section{Future Law and Policy Recommendations}

Considering the pace of scientific and technological development and the fundamental human rights at stake, particularly from a disability perspective and in acknowledgement of the rights of persons with disabilities, governmental controls are needed and an appropriate legislative framework is ultimately desirable not only to regulate access to and use of genetic information, but also to prevent the misuse and misapplication of emerging genetic technologies, such as gene editing. In the absence of controls and regulations, scientists inevitably will proceed with scientific and technological developments, which will become increasingly more accessible in medical and non-medical settings.

Prior to and in conjunction with any legislative endeavours, however, there needs to be in-depth and focused discussion and consultation with the stakeholders involved, including employer organisations, insurance organisations, lawyers and policy makers, advocates, and individuals across the spectrum of disability and their families and supporters. In considering the way forward to addressing and regulating genetic technologies, it is particularly important that the disability community and its advocacy groups are involved in this debate. Public consultation and engagement on these issues is desirable to ensure transparency and gauge the public's attitude and perception of these issues. This endeavour would contribute towards improving public confidence in this area, in line with the objective of the above recommendations.

In addition to foundational protections in legislation, there is a need to consider an awareness raising and educational campaign (as is advocated in the CRPD), to target medical professionals, commercial entities and the general public. There is a need to raise awareness and educate as to the benefits and limitations of genetic science and technology, the potential for misuse of these technologies, as well as the legal protections in place. In the United States, for example, there is still a lack of awareness of the legal protections in place and individuals are concerned about the misuse of genetic information, even following the introduction of federal level legislation in this field [154-159].

\section{Conclusions}

A major challenge of the 21st century will be to find new and effective ways to close the gap between disability law and technology, acknowledge emerging legal and ethical concerns, while at the same time allowing science to progress for the benefit of all. 
Advances in genetic science and technology are pushing the boundaries of modern medicine and healthcare. Rapid advances in the field of genetics throughout the 20th and 21st centuries, culminating in the success of the Human Genome Project, have accelerated the pace of genetic discoveries and resulted in unprecedented technological innovation. As well as detecting future disease and disabilities through genetic testing and other screening techniques such as PGD, emerging genetic technologies such as gene editing are attempting to eradicate disabilities and disease, potentially changing the landscape of the medical field and offering to change the delivery of healthcare in the future, with the promise of precision medicine.

However, the rapid pace of development in the field of genetics gives rise to a range of ethical, legal and regulatory concerns. As a society, it is important to maintain vigilance on the implications and unintended consequences of developing genetic technologies on individuals and families, in commercial contexts such as employment, and on societal values in general. Persons with disabilities and those with genetic predispositions to disability are vulnerable to mistreatment in this new genetic age, and their rights need to be acknowledged and protected.

On addressing the fundamental human rights at stake, together with an awareness of the history of the eugenics movement which acts as a stark reminder of the abuse of genetic science, this article proposes that the social model of disability provides an important human rights framework from which to view and address the issues that arise at the intersection of advancing genetic science and disability. In conjunction with the theory of the social model, the CRPD (together with the relevant soft law framework) provides an international forum for discussion and may initiate consideration of best practice around genetics and disability law and policy. This article recommends the use of the CRPD as a key framework and lens for viewing the use and control of genetic technologies. The CRPD shall act as an impetus for future legislative interventions, which are needed in this area. In addition to a comprehensive legislative framework, there is a need for awareness raising and educational campaigns as well as engagement and consultation on these issues from all stakeholders.

Author Contributions: Aisling de Paor and Peter Blanck both conducted the research carried out in this article, and both wrote this article.

Conflicts of Interest: The authors declare no conflict of interest.

\section{References and Notes}

1. Francis S. Collins, and Harold Varmus. "A New Initiative on Precision Medicine." New England Journal of Medicine 372 (2015): 793-95. [CrossRef] [PubMed]

2. Peter Blanck. eQuality: The Struggle for Web Accessibility by Persons with Cognitive Disabilities. New York: Cambridge University Press, 2014.

3. Peter Blanck, and Jonathan Martinis. "'The Right to Make Choices': National Resource Center for Supported Decision-Making." Inclusion 3 (2015): 24-33. [CrossRef]

4. Peter Blanck. "ADA at 25 and People with Cognitive Disabilities: From Voice to Action." Inclusion 3 (2015): 46-54. [CrossRef]

5. Jackie Leach Scully. “Disability and genetics in an era of genomic medicine." Nature Reviews Genetics 9 (2008): 797-802. [CrossRef] [PubMed]

6. Aisling de Paor, and Noel Lowndes. "Tracing the History, Evolution and Future Orientation of Genetic Science and Technology." In Genetic Discrimination-Transatlantic Perspectives on the Case for a European Level Legal Response. Edited by Gerard Quinn, Aisling de Paor and Peter Blanck. New York: Routledge, 2014.

7. Francis S. Collins, and Victor A. McKusick. "Implications of the Human Genome Project for Medical Science." Journal of the American Medical Association 285 (2001): 540-44. [CrossRef] [PubMed]

8. Leslie P. Francis. "You Are Born with Your Genes: Justice and Protection against Discrimination in the Use of Genetic Information." Mount Sinai Journal of Medicine 77 (2010): 188-96. [CrossRef] [PubMed]

9. Margaret A. Hamburg, and Francis S. Collins. "The Path to Personalized Medicine." New England Journal of Medicine 363 (2010): 301-4. [CrossRef] [PubMed] 
10. Paul Steven Miller. "Is there a pink slip in your genes? Genetic discrimination in the workplace." Journal of Health Care Law and Policy 3 (2000): 225-65. [PubMed]

11. Peter S. Harper. "What do we mean by genetic testing?" Journal of Medical Genetics 34 (1997): 749-52. [CrossRef] [PubMed]

12. Melinda B. Kaufman. "Genetic Discrimination in the Workplace: An Overview of Existing Protections." Loyola University Chicago Law Journal 30 (1999): 397-98.

13. Cynthia Garcia Coll, Elaine L. Bearer, and Richard M. Lerner. Nature and Nurture: The Complex Interplay of Genetic and Environmental Influences on Human Behaviour and Development. New York and London: Lawrence Erlbaum, 2004.

14. Mary Jeanne Kreek, David A. Nielsen, Eduardo R. Butelman, and K. Steven LaForge. “Genetic Influences on impulsivity, risk-taking, stress, responsibility and vulnerability to drug abuse and addiction." Nature Neuroscience 8 (2005): 1450-57. [CrossRef] [PubMed]

15. The increase in interest and availability of DTC genetic testing is partly the result of the emergence of several companies, such as: 23andMe (https://www.23andme.com/).

16. Stuart Hogarth, Gail Javitt, and David Melzer. “The Current Landscape for Direct-to-Consumer Genetic Testing: Legal, Ethical and Policy Issues." Annual Review of Human Genomics and Human Genetics 9 (2008): 161-82. [CrossRef] [PubMed]

17. John Lynch, Ashley Parrott, Robert J. Hopkin, and Melanie Myers. “Media Coverage of Direct-to-Consumer Genetic Testing." Journal of Genetic Counselling 20 (2011): 486-94. [CrossRef] [PubMed]

18. Pauline C. Ng, and Ewen F. Kirkness. "Whole Genome Sequencing." Genetic Variation—Methods in Molecular Biology 628 (2010): 215-26.

19. Kelly E. Ormond, Matthew T. Wheeler, Louanne Hudgins, Teri E. Klein, Atul J. Butte, Russ B. Altman, Euan A. Ashley, and Henry T. Greely. "Challenges in the clinical application of whole-genome sequencing." The Lancet 375 (2010): 1749-51. [CrossRef]

20. Tanya Lewis. "This genetics company claims it can sequence and analyze your entire genome for $\$ 999 . "$ Business Insider UK, 2016. Available online: http:/ / uk.businessinsider.com/veritas-genetics-launches-1000genome-test-2016-3?r=US\&IR=T (accessed on 23 March 2016).

21. Gina Kolata. "In Gene Sequencing Treatment for Leukemia, Glimpses into the Future." New York Times, 7 July 2012. Available online: http://www.nytimes.com/2012/07/08/health/in-gene-sequencingtreatment-for-leukemia-glimpses-of-the-future.html?pagewanted=all (accessed on 5 March 2016).

22. Elaine R. Mardis, and Richard K. Wilson. "Cancer Genome Sequencing: A Review." Human Molecular Genetics, Review Issue 18 (2009): R163-68. [CrossRef] [PubMed]

23. Stefan Timmermans, and Mara Buchbinder. Saving Babies-The Consequences of Newborn Genetic Screening. Chicago: University of Chicago Press, 2013, p. 7.

24. Karen Sermon, André Van Steirteghem, and Inge Liebaers. "Preimplantation genetic diagnosis." The Lancet 363 (2004): 1633-41. [CrossRef]

25. Peter Braude, Susan Pickering, Frances Flinter, and Caroline Mackie Ogilvie. "Preimplantation genetic diagnosis." Nature Reviews Genetics 3 (2002): 941-55. [CrossRef] [PubMed]

26. Martin Harvey. "Reproductive Autonomy Rights and Disenhancement: Sidestepping the Argument from Backhanded Benefit." Journal of Applied Philosophy 21 (2004): 125-40. [CrossRef] [PubMed]

27. Erik Parens, and Adrienne Asch. “Disability Rights Critique of Prenatal Genetic Testing: Reflections and Recommendations." Mental Retardation and Developmental Disabilities Research Reviews 9 (2003): 40-47. [CrossRef] [PubMed]

28. Heidi Ledford. "CRISPR, the Disruptor-A powerful gene-editing technology is the biggest game changer to hit biology since PCR. But with its huge potential come pressing concerns." Nature 522 (2015): 20-21. [CrossRef] [PubMed]

29. Hui-Ying Xue, Li-Juan Ji, Ai-Mei Gao, Ping Liu, Jing-Dong He, and Xiao-Jie Lu. “CRISPR-Cas9 for medical genetic screens: applications and future perspectives." Journal of Medical Genetics 53 (2016): 91-97. [CrossRef] [PubMed]

30. Ewen Callaway. "UK scientists gain licence to edit gene in human embryos." Nature 530 (2016): 18. [CrossRef] [PubMed]

31. Anna Arstein-Kerslake, Michelle Browning, Joanne Watson, Jonathan Martinis, and Peter Blanck. "Future Directions in Supported Decision-Making Research." Disability Studies Quarterly, 2016, submitted. 
32. Rebecca Wolf, Michael Joseph Young, Michael Ashley Stein, and Harold J. Bursztajn. “Genes, identity and clinical ethics under conditions of uncertainty." In Genetic Discrimination-Transatlantic Perspectives on the Case for a European Level Legal Response. Edited by Gerard Quinn, Aisling de Paor and Peter Blanck. New York: Routledge, 2014, p. 52.

33. Lisa Schur, Douglas Kruse, and Peter Blanck. People with Disabilities: Sidelined or Mainstreamed? New York: Cambridge University Press, 2013.

34. Neil A. Holtzman, Patricia D. Murphy, Michael S. Watson, and Patricia A. Barr. "Predictive Genetic Testing: From Basic Research to Clinical Practice." Science 278 (1997): 602-5. [CrossRef] [PubMed]

35. Roy Deodutta, and Dorah Tevfile. Environmental Factors, Genes and Development of Human Cancers. New York: Springer, 2010.

36. Aisling de Paor. "Disability and Genetics—New forms of discrimination." In Routledge Handbook on Disability Law and Human Rights. Edited by Peter Blanck and Elionoir Flynn. New York: Routledge, 2016.

37. James P. Evans, Cécile Skrzynia, and Wylie Burke. "The Complexities of Predictive Genetic Testing." British Medical Journal 322 (2001): 1052-56. [CrossRef] [PubMed]

38. David Benjamin Turitz-Cox, Randall Jeffrey Platt, and Feng Zhang. "Therapeutic genome editing: Prospects and challenges." Nature Medicine 21 (2015): 121-31.

39. Tom Shakespeare. "Choices and Rights: eugenics, genetics and disability equality." Disability and Society 13 (1998): 665-81. [CrossRef] [PubMed]

40. Paul Steven Miller, and Rebecca Leah Levine. "Avoiding genetic genocide: Understanding good intentions and eugenics in the complex dialogue between the medical and disability communities." Genetic Medicine 15 (2013): 95-102. [CrossRef] [PubMed]

41. Tom Shakespeare. "Disability, Genetic and Global Justice." Social Policy E Society 4 (2005): 87-95.

42. World Health Organization. "World Report on Disability." 2011. Available online: http://www.who.int/ disabilities/world_report/2011/report.pdf (accessed on 25 August 2016).

43. Shawna Benston. "CRISPR, a Crossroads in Genetic Intervention: Pitting the Right to Health against the Right to Disability." Laws 5 (2016): 5. [CrossRef]

44. Paul Steven Miller. "Genetic Testing and the Future of Disability Insurance: Thinking about Discrimination in the Genetic Age." Journal of Law, Medicine and Ethics 35 (2007): 47-51. [CrossRef] [PubMed]

45. Gregor Wolbring. "Ability Privilege: A Needed Addition to Privilege Studies." Journal of Critical Animal Studies 12 (2014): 118-41.

46. Larry Logue, and Peter Blanck. Race, Ethnicity, and Disability: Veterans and Benefits in Post-Civil War America. New York: Cambridge University Press, 2010.

47. Bruce G. Link, and Jo C. Phelan. "Stigma and its public health implications." The Lancet 367 (2006): 528-29. [CrossRef]

48. Norman Sartorious. "Stigma and Mental Health." The Lancet 370 (2007): 810-11. [CrossRef]

49. Peter McGuffin, and Neilson Martin. “Behaviour and genes.” British Medical Journal 319 (1999): 37-40. [CrossRef] [PubMed]

50. Otto F. Wahl, and Charles R. Harman. "Family views of stigma." Schizophrenia Bulletin 15 (1989): 131-39. [CrossRef] [PubMed]

51. Otto F. Wahl. "Mental health consumers' experience of stigma." Schizophrenia Bulletin 25 (1999): 467-78. [CrossRef] [PubMed]

52. Peter Blanck, Michael Waterstone, and William Myhill. Disability Civil Rights Law and Policy: Case and Materials, 3rd ed. Eagan: West Publishers, 2014.

53. Lynne Walsh. “The impact of mental health problems in the workplace." British Journal of Wellbeing 2 (2011): 32-35. [CrossRef]

54. Heather Stuart. "Mental illness and employment discrimination." Current Opinion in Psychiatry 19 (2006): 522-26. [CrossRef] [PubMed]

55. Jerome Bickenbach. "The Perils of Human Genetics." Ethics and Intellectual Disability 1 (1996): 1-3. [PubMed]

56. Francis Galton. Inquiries into Human Faculty and Its Development. Darlington: Dent and Sons, 1907.

57. Willi Rothley, and Carlo Casini. Ethical and Legal Problems of Genetic Engineering and Human Artificial Insemination. Luxembourg City: EU Committee on Legal Affairs and Citizen's Rights, 1990.

58. David J. Galton, and Claire J. Galton. "Francis Galton: and eugenics today." Journal of Medical Ethics 24 (1998): 99-105. [CrossRef] [PubMed] 
59. Peter Blanck, and Aisling de Paor. "US legislative and policy response: Some historical context to GINA." In Genetic Discrimination-Transatlantic Perspectives on the Case for a European Level Legal Response. Edited by Gerard Quinn, Aisling de Paor and Peter Blanck. New York: Routledge, 2014, pp. 98-99.

60. Kenneth L. Garver, and Bettylee Garver. "The Human Genome project and Eugenic Concerns." American Journal of Human Genetics 54 (1994): 148-58. [PubMed]

61. Iulia V. Motoc. “The International Law of Genetic Discrimination: The Power of Never Again." In New Technologies and Human Rights. Edited by Therese Murphy. Oxford: Oxford University Press, 2009.

62. M. Michael Cohen, Jr. “Overview of German, Nazi and Holocaust Medicine.” American Journal of Medical Genetics Part A 152 (2010): 687-707. [CrossRef] [PubMed]

63. Rael D. Strous. "Hitler's Psychiatrists: Healers and Researchers Turned Executioners and Its Relevance Today." Harvard Review of Psychiatry 14 (2006): 30-37. [CrossRef] [PubMed]

64. Daniel Kevles. "Eugenics and Human Right." British Medical Journal 319 (1999): 435-38. [CrossRef] [PubMed]

65. Daniel Kevles. In the Name of Eugenics: Genetics and the Uses of Human Heredity. Cambridge: Harvard University Press, 1985, p. 62.

66. Lori B. Andrews. "Past as Prologue: Sobering Thoughts on Genetic Enthusiasm." Seton Hall Law Review 27 (1997): 893-918. [PubMed]

67. Edward J. Larson. "Confronting Scientific Authority with Religious Values: Eugenics in American History." In Genetic Engineering: A Christian Response-Crucial Considerations in Shaping Life. Edited by Timothy J. Demy and Gary P. Stewards. Grand Rapids: Kregal Publications, 1999, pp. 105-6.

68. Morse Hyun-Myung Tan. "Advancing Civil Rights, the Next Generation: The Genetic Information Non Discrimination Act of 2008 and Beyond." Health Matrix 19 (2009): 63-119. [PubMed]

69. Oliver Wendell Holmes, Jr. “Buck v Bell 274 U.S. 200 (1927).” Available online: https:/ / supreme.justia.com/ cases/federal/us/274/200/case.html (accessed on 25 August 2016).

70. Troy Duster. Backdoor to Eugenics, 2nd ed. London and New York: Routledge, 2003.

71. Peter Chipman. "The moral implications of prenatal testing." Penn Bioethics Journal 2 (2006): 13-16. [PubMed]

72. Mary B. Mahowald. "Prenatal testing for selection against disabilities." Cambridge Quarterly of Healthcare Ethics 16 (2007): 457-62. [CrossRef] [PubMed]

73. Deirdre Madden. Medicine, Ethics and Law, 2nd ed. London: Bloomsbury Professional, 2011, pp. 330-31.

74. Glenn E. McGee. The Perfect Baby: A Pragmatic Approach to Genetics. Lanham: Rowman and Littlefield Publishers, 1997, p. 111.

75. Bratislav Stankovic. "It's a Designer Baby!': Opinions on Regulation of Preimplantation Genetic Diagnosis." UCLA Journal of Law and Technology 3 (2005): 1-31.

76. Karen E. Schiavone. "Playing the Odds or Playing God? Limiting Parental Ability to Create Disabled Children through Preimplantation Genetic Diagnosis." Albany Law Review 73 (2010): 283-328.

77. Sonia Suter. “A Brave New World of Designer Babies.” Berkeley Technology Law Journal 22 (2007): 897-969.

78. Cara Mand, Rony E. Duncan, Lynn Gillam, V. Collins, and Martin B. Delatycki. “Genetic Selection for Deafness: the views of hearing children of deaf adults." Journal of Medical Ethics 35 (2009): 722-28. [CrossRef] [PubMed]

79. Dimitrius Anastasiou, and James Kauffman. "The Social Model of Disability: Dichotomy between Impairment and Disability." Journal of Medicine and Philospohy 28 (2013): 441-59. [CrossRef] [PubMed]

80. Tom Shakespeare. Disability Rights and Wrongs. London: Routledge, 2013.

81. James D. Watson, and Francis H. C. Crick. "Molecular Structure of Nucleic Acids: A Structure for Deoxyribose Nucleic Acid." Nature 171 (1953): 737-38. [CrossRef] [PubMed]

82. James Watson. A Passion for DNA. Oxford: Oxford University Press, 2000.

83. Michael Oliver. Understanding Disability: From Theory to Practice. New York: St Martin's Press, 1996.

84. Vic Finkelstein. "'We' are not disabled, 'you' are." In Constructing Deafness. Edited by Susan Gregory and Gillian Hartley. London: Continuum, 1990.

85. Rhidian Hughes. “The social model of disability.” British Journal of Healthcare Assistants 4 (2010): 508-11. [CrossRef]

86. Mike Oliver. “The Social Model of Disability—Thirty Years on.” Disability and Society 28 (2013): 1024-26. [CrossRef]

87. Lisa Shur, Douglas Kruse, and Peter Blanck. People with Disabilities—Sidelined or Mainstreamed? Cambridge: Cambridge University Press, 2013, p. 9. 
88. Mark Priestley. “Constructions and Creations: Idealism, Materialism and Disability Theory." Disability and Society 13 (1998): 75-94. [CrossRef]

89. Julian Savulescu. Enhancing Human Capacities. Chichester: Blackwell Publishing, 2011.

90. Julian Savulescu. "Procreative Beneficence: Why We Should Select the Best Children." Bioethics 15 (2001): 414-35. [CrossRef]

91. Rosamund Scott. "Choosing between possible lives: Legal and Ethical Issues in Preimplantation Genetic Diagnosis." Oxford Journal of Legal Studies 26 (2006): 153-178. [CrossRef] [PubMed]

92. Sarah Stoller. "Why we are not morally required to select the best children: A response to Savulescu." Bioethics 22 (2008): 364-69. [CrossRef] [PubMed]

93. Immaculada de Melo-Martin. "On our obligation to select the best children: A reply to Savulescu." Bioethics 18 (2004): 72-83. [CrossRef] [PubMed]

94. Adrienne Asch. “Disability, equality and prenatal testing: Contradictory or compatible?" Florida State University Law Review 30 (2003): 315-42. [PubMed]

95. Adrienne Asch. "Prenatal diagnosis and selective abortion: A challenge to practice and policy." American Journal of Public Health 89 (1999): 1649-57. [CrossRef] [PubMed]

96. Aisling de Paor. "US and EU Perspectives on Genetic Discrimination in Employment and Insurance: Striking a Balance in a Battlefield of Competing Rights." In European Yearbook of Disability Law. Edited by Gerard Quinn, Lisa Waddington and Eilionoir Flynn. Antwerp: Intersentia, 2013, vol. 3, pp. 99-119.

97. Colin S. Diver, and Jane Maslow Cohen. "Genophobia: What Is Wrong with Genetic Discrimination?" University of Pennsylvania Law Review 149 (2001): 1439-82. [CrossRef] [PubMed]

98. Aisling de Paor. "Regulating Genetic Information-Exploring the Options in Legal Theory." European Journal of Health Law 21 (2014): 425-53. [CrossRef] [PubMed]

99. Genetic information is familial information, and the shared or familial nature of genetic information therefore expands the group or percentage of individuals vulnerable to misuse on grounds of genetic make up.

100. Mark A. Rothstein, and Bartha Knoppers. "Legal Aspects of Genetics, Work and Insurance in North America and Europe." European Journal of Health Law 3 (1996): 143-61. [CrossRef] [PubMed]

101. Susannah Carr. "Invisible Actors: Genetic Testing and Genetic Discrimination in the Workplace." University of Arkansas at Little Rock Law Review 30 (2007-2008): 1-17.

102. Paul R. Billings, Mel A. Kohn, Margaret De Cuevas, Jonathan Beckwith, Joseph Alper, and Marvin Natowicz. “Discrimination as a Consequence of Genetic Testing." American Journal of Human Genetics 50 (1992): 476-82. [PubMed]

103. Marvin R. Natowicz, Jane K. Alper, and Joseph S. Alper. "Genetic Discrimination and the Law." American Journal of Human Genetics 50 (1992): 465-66. [PubMed]

104. Michael S. Yesley. "Protecting Genetic Difference." Berkeley Technology Law Review 13 (1999): 653-65.

105. Margaret Otlowski, Mark Stranger, Sandra Taylor, Kristine Barlow-Stewart, and Susan Treloar. "Practices and Attitudes of Australian Employers in relation to the use of genetic information: Report on a National Study." Comparative Labor Law and Policy Journal 31 (2010): 637-38.

106. Mark A. Rothstein. "Genetic Discrimination in Employment: Ethics, Policy and Comparative Law." In Human Genetic Analysis and the Protection of Personality and Privacy. Edited by Swiss Institute of Comparative Law. Zurich: Schulthess Polygraphisher Verlag, 1994, p. 129.

107. Aisling de Paor. "The Regulation of Genetic Information in Ireland-Does it strike an appropriate balance of rights?" Medico-Legal Journal of Ireland 19 (2013): 97-98.

108. Peter Blanck. "The Struggle for Web Equality by Persons with Cognitive Disabilities." Behavioral Sciences $\mathcal{E}$ the Law 32 (2014): 4-32. [CrossRef] [PubMed]

109. Mark Taylor. Genetic Data and the Law: A Critical Perspective on Privacy Protection. Cambridge: Cambridge University Press, 2012.

110. For example, Convention for the Protection of Human Rights and Fundamental Freedoms ETS 5; 213 UNTS 221, Article 8. Available online: http://www.echr.coe.int/Documents/Convention_ENG.pdf (accessed on 25 August 2016).

111. Sonia Suter. "Disentangling Privacy from Property: Toward a Deeper Understanding of Genetic Privacy." The George Washington Law Review 72 (2004): 737-814. [PubMed]

112. Graeme Laurie. Genetic Privacy-A Challenge to Medico-Legal Norms. Cambridge: Cambridge University Press, 2002, p. 153. 
113. “Council Directive 89/391/EEC of 12 June 1989 on the introduction of measures to encourage improvements in the safety and health of workers at work [1989] OJ L 183/1." Available online: http:/ /eur-lex.europa.eu/ legal-content/EN/TXT/?uri=OJ:L:1989:183:TOC (accessed on 25 August 2016).

114. Michael Baram. “Genetic Testing for Susceptibility to Disease from Exposure to Toxic Chemicals: Implications for Public and Worker Health Policies." Jurimetrics 41 (2001): 165-76.

115. Rainer Strohmenger, and Achim Wambach. "Adverse selection and categorical discrimination in the health insurance markets: The effects of genetic tests." Journal of Health Economics 19 (2000): 197-218. [CrossRef]

116. Robert J. Pokorski. "Use of Information by Private Insurers." In Justice and the Human Genome Project. Edited by Thomas F. Murphy and Marc A. Lappe. Berkeley: California University Press, 1994, p. 91.

117. Roberta M. Meyer. "Justification for Permitting Life Insurers to Continue to Underwrite on the Basis of Genetic Information and Genetic Test Results." Suffolk University Law Review 27 (1993): 1271-305. [PubMed]

118. Tuija Takala. "The Right to Genetic Ignorance Confirmed." Bioethics 13 (1999): 288-93. [CrossRef] [PubMed]

119. Erik Parens. "Drifting Away from Informed Consent in the Era of Personalized Medicine." Hastings Center Report 45 (2015): 16-20. [CrossRef] [PubMed]

120. Hugh Miller. "DNA blueprints, personhood and genetic privacy." Health Matrix 8 (1998): 179-207. [PubMed]

121. Gerard Quinn. Rethinking Personhood: New Directions in Legal Capacity Law and Policy. Vancouver: University of British Colombia, 2011.

122. For further discussion of the theory of genetic determinism, see George P. Smith II, and Thaddeus J. Burns. "Genetic Determinism or Genetic Discrimination?" Journal of Contemporary Health Law and Policy 11 (1995): 23-61.

123. Henry T. Greely. "Legal, Ethical, and Social Issues in Human Genome Research." Annual Review of Anthropology 27 (1998): 473-502. [CrossRef] [PubMed]

124. Jennifer Fitzgerald. "Geneticizing Disability: The Human Genome Project and the Commodification of Self." Issues in Law and Medicine 14 (1999): 147-52.

125. Robert Dinerstein. "Implementing Legal Capacity Under Article 12 of the UN Convention on the Rights of Persons with Disabilities: The Difficult Road from Guardianship to Supported Decision-Making." Human Rights Brief 19 (2012): 8-12.

126. Colin Barnes. “The Social Model of Disability: A Sociological Phenomenon Ignored by Sociologists?" In Disability Reader: Social Science Perspectives. Edited by Tom Shakespeare. London: Continuum, 1998.

127. The General Assembly. "United Nations Convention on the Rights of Persons with Disabilities (CRPD), A/Res/61/106." 2006. Available online: http://www.un.org/en/ga/search/view_doc.asp?symbol=A/ RES/61/106\&Lang=E (accessed on 25 August 2016).

128. Gerard Quinn. "The United Nations Convention on the Rights of Persons with Disabilities: Toward a New International Politics of Disability." Texas Journal on Civil Liberties and Civil Rights 15 (2010): 33-52.

129. Janet Lord. "Screened out of Existence: The Convention on the Rights of Persons with Disabilities and Selective Screening Policies." International Journal of Disability, Community and Rehabilitation, 2012. Available online: http://www.ijdcr.ca/VOL12_02/articles/lord.shtml (accessed on 25 August 2016).

130. Lisa Waddington. "Breaking New Ground: The Implications of Ratification of the UN Convention on the Rights of Persons with Disabilities for the European Community." In UN Convention on the Rights of Persons with Disabilities. Edited by Oddný Mjöll Arnardóttir and Gerard Quinn. Leiden: Martinus Nijhoff Publishers, 2009, p. 115.

131. CRPD, Article 1.

132. Michael Stein, and Janet Lord. "Future Prospects for the United Nations Convention on the Rights of Persons with Disabilities." In UN Convention on the Rights of Persons with Disabilities. Edited by Oddný Mjöll Arnardóttir and Gerard Quinn. Leiden: Martinus Nijhoff Publishers, 2009, p. 25.

133. Delia Ferri. "The Conclusion of the UN Convention on the Rights of Persons with Disabilities by the EC/EU." In European Yearbook of Disability Law. Edited by Gerard Quinn and Lisa Waddington. Antwerp: Intersentia, 2010, vol. 2, p. 52.

134. Janet Lord. "Accommodating Genes: Disability, Discrimination and International Human Rights Law." In Genetic Discrimination-Transatlantic Perspectives on the Case for a European Level Legal Response. Edited by Gerard Quinn, Aisling de Paor and Peter Blanck. New York: Routledge, 2014, pp. 226-33. 
135. CRPD, Preamble (h).

136. CRPD, Article 3 (b).

137. CRPD, Article 5.

138. Gerard Quinn. "Disability and Human Rights: A New Field in the United Nations." In International Protection of Human Rights: A Textbook, 2nd ed. Edited by Caterina Krause and Martin Schenin. Turku: Abo Akademi University for Human Rights, 2012, p. 279.

139. CRPD, Article 27.

140. CRPD, Article 3.

141. Prenatal screening for Down Syndrome has been adopted in a number of jurisdictions to screen out the condition (for example, New Zealand and Denmark).

142. Erika Check Hayden. “Tomorrow's children-What would genome editing really mean for future generations?" Nature 530 (2016): 402-5.

143. Aisling de Paor. "International Human Rights Perspectives on the Protection of Genetic Information-Exploring the Scope and Impact of the Current United Nations Framework." Journal of Law and Public Policy 2 (2015): 16-35.

144. CRPD. Article 8.

145. Elizabeth Emens. "Disabling Attitudes: U.S. Disability Law and the ADA Amendments Act." American Journal of Comparative Law 60 (2012): 205. [CrossRef]

146. The General Assembly. "A/Res/152, UN GAOR, 53 ${ }^{\text {rd }}$ Sess., UN. Doc A/53/625/Add.2 (1998)." Available online: http://www.un.org/en/ga/search/view_doc.asp?symbol=A/RES/53/152 (accessed on 25 August 2016).

147. UNESCO. “International Declaration on Human Genetic Data." 16 October 2003. Available online: http:// www.unesco.org/new/en/social-and-human-sciences/themes/bioethics/human-genetic-data/ (accessed on 25 August 2016).

148. Abdulqawi A. Yusuf. "UNESCO Standard-setting Activities on Bioethics: Speak Softly and Carry a Big Stick." In Biotechnologies and International Human Rights. Edited by Francesco Francioni. Oxford and Portland: Hart Publishing, 2007, pp. 85-91.

149. UNESCO. "Universal Declaration on Bioethics and Human Rights." 19 October $2005 . \quad$ Available online: http:/ / portal.unesco.org/en/ev.php-URL_ID=31058\&URL_DO=DO_TOPIC\&URL_SECTION=201. html (accessed on 25 August 2016).

150. Roberto Andorno. "Global Bioethics at UNESCO: In defence of the Universal Declaration on Bioethics and Human Rights." Journal of Medical Ethics 33 (2007): 150-54. [CrossRef] [PubMed]

151. Souheil El-Zein. "Genetic Manipulation: How to Strike the Right Balance between Technology and Respect for Human Rights." In Realizing Utopia-The Future of International Law. Edited by Antonio Cassese. Oxford: Oxford University Press, 2012, p. 489.

152. Jennifer Tauer. "International Protection of Genetic Information: The Progression of the Human Genome Project and the Current Framework of Human Rights Doctrines." Denver Journal of International Law and Policy 29 (2001): 209-37. [PubMed]

153. Therese Murphy. "Taking Revolutions Seriously: Rights, Risk and New Technologies." Maastricht Journal 16 (2009): 15-39.

154. Samuel W. Anderson. "Genetic Privacy Worries on the Rise-Interview with Christy White." Cogent Research, 2011. Available online: http:/ /www.councilforresponsiblegenetics.org/genewatch/GeneWatchPage.aspx? pageId=324\&archive=yes (accessed on 25 August 2016).

155. Robert Klitzman. “Views of Discrimination among Individuals Confronting Genetic Disease." Journal of Genetic Counseling 19 (2010): 68-83. [CrossRef] [PubMed]

156. Amanda L. Laedtke, Suzanne M. O’Neill, Wendy S. Rubinstein, and Kristen J. Vogel. "Family Physicians' Awareness and Knowledge of the Genetic Information Non-Discrimination Act (GINA)." Journal of Genetic Counseling 21 (2012): 345. [CrossRef] [PubMed]

157. Dawn C. Allain, Sue Friedman, and Leigha Senter. "Consumer awareness and attitudes about insurance discrimination post enactment of the Genetic Information Non-Discrimination Act." Familial Cancer 11 (2012): 637-44. [CrossRef] [PubMed] 
158. Susanne B. Haga, William T. Barry, Rachel Mills, Geoffrey S. Ginsburg, Laura Svetkey, Jennifer Sullivan, and Huntington F. Willard. "Public knowledge of and attitudes toward genetics and genetic testing." Genetic Testing and Molecular Biomarkers 17 (2013): 327-35. [CrossRef] [PubMed]

159. Peter Blanck. "The First 'A' in the ADA: And 25 More 'A' s Toward Equality for Americans With Disabilities." Inclusion 4 (2016): 46-51. [CrossRef]

(C) 2016 by the authors; licensee MDPI, Basel, Switzerland. This article is an open access article distributed under the terms and conditions of the Creative Commons Attribution (CC-BY) license (http://creativecommons.org/licenses/by/4.0/). 